\title{
Molecular characterization of Listeria monocytogenes isolated from animal products in a city of Northern Brazil
}

\author{
Caracterização molecular de Listeria monocytogenes isolada de produtos de origem animal em \\ uma cidade da região Norte do Brasil
}

\author{
Lilyan Rosmery Luizaga de Monteiro ${ }^{\mathrm{I}}$ Albenones José de Mesquita ${ }^{\mathrm{II}}$ \\ Maria Cláudia Dantas Porfirio Borges André ${ }^{I I I}$ Juliana Lamaro Cardoso ${ }^{\text {III }}$
}

\section{ABSTRACT}

Listeria monocytogenes, a foodborne pathogen causes listeriosis, a fatal disease in about $30 \%$ of cases that affects mainly immunocompromised persons. The aim of this research was to characterize L. monocytogenes pulsed-field gel electrophoresis (PFGE) types isolated from meat products collected at public markets in Araguaina city, TO. Sixty samples of raw ground beef and frescal sausage were analyzed during the second half of 2008. Five out of 30 samples (16.7\%) of raw ground beef tested positive for $\mathbf{L}$. monocytogenes, three of which were classified as serotype $1 / 2 b$ and two as serotype $4 b$. Among the 30 samples of sausage collected, two strains of $\boldsymbol{L}$. monocytogenes were isolated (6.7\%), one of them belonging to serotype $1 / 2 a$ and the other belonging to serotype $1 / 2 b$. The restriction enzymes used were ApaI and SmaI. Similarities among the strains were determined by Dice coefficient. The macro restriction profile obtained by using SmaI enzyme allowed the distribution of seven strains in two clusters, two pulsotypes and two subtypes. The result indicates that $\boldsymbol{L}$. monocytogenes isolates, belonging to serotype $4 b, 1 / 2 a$ and $1 / 2 b$, are strongly correlated within the same serotype group, and in some cases among different serotypes, suggesting that they have a common source.

Key words: pulsed field gel electrophoresis, ground beef, frescal sausage, $L$. monocytogenes.

\section{RESUMO}

Listeria monocytogenes é um patógeno de origem alimentar que causa a listeriose, doença fatal em aproximadamente $30 \%$ dos casos, e que afeta principalmente pessoas imunocomprometidas. $O$ presente trabalho teve como objetivo analisar os perfis PFGE de cepas de L. monocytogenes isoladas de produtos de origem animal, obtidos em mercados públicos da cidade de Araguaína, TO. Foram analisadas 60 amostras de carne moída crua e de linguiça frescal, no segundo semestre de 2008. Cinco (16,7\%) das 30 amostras de carne moída crua foram positivas ao patógeno, sendo que três pertenciam ao sorotipo $1 / 2 b$ e duas ao sorotipo $4 b$. Das 30 amostras de linguiça mista frescal, duas $(6,7 \%)$ foram positivas para L. monocytogenes, sendo uma do sorotipo 1/2a e outra do 1/2b. Foram utilizadas as enzimas de restrição ApaI e SmaI. A similaridade entre eles foi determinada pelo coeficiente de Dice. A análise do perfil de macrorestrição com a enzima SmaI permitiu a distribuição dos sete isolados em dois clusters, dois pulsotipos e dois subtipos. Os resultados permitiram concluir que os isolados de L. monocytogenes sorotipos $4 b, 1 / 2 a$ e $1 / 2 b$ foram fortemente correlacionados dentro dos mesmos sorotipos e em alguns casos entre diferentes sorotipos, sugerindo uma fonte comum.

Palavras-chave: eletroforese em gel de campo pulsado, carne moída, linguiça frescal.

\section{INTRODUCTION}

Listeria monocytogenes is a foodborne pathogen responsible for sporadic outbreaks of listeriosis that can cause septicemia, meningitis, meningoencephalitis and abortion. Listeriosis is fatal in about $30 \%$ of cases and mainly affects immunocompromised people, pregnant women, newborn babies and the elderly (PARIHAR et al., 2008; FILIOUSIS et al., 2009). This ubiquitous pathogen is particularly important because of its ability to multiply at low temperatures and under high salt concentrations. Moreover, it has the ability to form biofilms (GRAVES et al., 2005; SHEN et al., 2006).

The genus Listeria contains six species: $\boldsymbol{L}$. monocytogenes,L.ivanovii,L.innocua,L.welshmeri,

ICampus Universitário de Araguaína, Universidade Federal do Tocantins (UFT), 77824-838, Araguaína, TO, Brasil. E-mail: luizaga@uft.edu.br. Autor para correspondência.

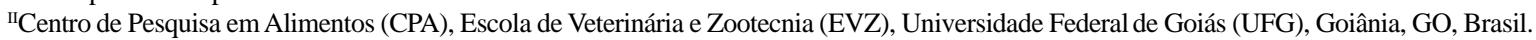

IIIInstituto de Patologia Tropical e Saúde Pública (IPTSP), UFG, Goiânia, GO, Brasil. 
L. seeligeri, and L. grayi. During the last two decades the group was divided as $L$. monocytogenes and nonpathogenic species (ROCOURT, 1999). Although Listeria monocytogenes is an ubiquitarius organism, genetic lineages among this species are detected, presenting a virulence heterogeneity which can also differ in their association with food and environmental sources (JACQUET et al., 2002; GRAY et al., 2004). GRAVES et al. (1999) divided the Listeria monocytogenes subtyping methods into two categories: conventional (serotyping, phage typing) and molecular methods (Multilocus Enzyme Electrophoresis - MEE; Chromossomal DNA Restriction Endonuclease Analysis - REA, Restriction Fragment Length Polymorphism Analysis - RFLPs).

Conventional techniques by themselves cannot detect the source of listeriosis outbreaks; however, molecular subtyping methods are an useful tool in this determination. Among these methods, pulsed-field gel electrophoresis (PFGE) offers great sensitivity along with a high discriminatory power, and it is considered the gold standard method for L. monocytogenes subtyping (TENOVER et al. 1997; FUGETT et al., 2007; LEMES-MARQUES et al., 2007). PFGE can also be used in long-term studies both to determine the persistence of a species in an environment, or for determining external contamination into an environment (SENCZEK et al., 2000; MORETRO \& LANGSRUD, 2004). Because of its specificity and sensitivity PFGE has been used for Listeria species typing replacing the serotyping technique (MELLO et al., 2008). Besides its good reproducibility this technique is highly discriminatory when compared with other molecular typing methods currently available (TENOVER et al. 1997; BASIM \& BASIM, 2001).

In Brazil, there is a lack of information about listeriosis outbreaks, antimicrobial susceptibility of clinical strains and their phenotypic and genotypic characterization. Along with the lack of control and study of listeriosis in Brazil, LEMES-MARQUES et al. (2007) include the difficulties in tracing the bacterial types involved in the outbreaks, the lack of notification and the delay in obtaining final results in conventional medical tests.

The aim of this study was to characterize L. monocytogenes strains isolated from raw ground beef and fresh mixed sausage sold in Araguaina, northern Brazil, by means of PFGE analysis in order to investigate any relationships among the strains.

\section{MATERIAL AND METHODS}

\section{Bacterial isolates}

Listeria monocytogenes was isolated from 30 samples of raw ground beef and from 30 samples of frescal sausage, obtained from butcher shops in Araguaina city, from August to December 2008. The strains were serotyped by the Bacteriology Department at the Oswaldo Cruz Institute, Rio de Janeiro (FIOCRUZ). The techniques of isolation, selection, confirmation and identification were in accordance with the Normative $\mathrm{n}^{\mathrm{o}}$. 62, from August 26, 2003 (BRASIL, 2003). After identification, the strains were frozen at $-20^{\circ} \mathrm{C}$ in a mixture of $50 \%$ Luria Bertani broth (LB) and 50\% glycerol.

\section{Pulsed-field gel electrophoresis}

The genetic profile of $L$. monocytogenes strains was determined by PFGE of DNA digested with the restriction enzymes ApaI and SmaI, and electrophoresed on a Chef DRII system (Bio-Rad Laboratories, Hercules, CA). PFGE patterns were classified as indistinguishable if the DNA fragment matched each other completely, as closely related if they differed by one to three bands, and as unrelated if they differed by more than three bands (TENOVER et al., 1995). Numbers were used to designate the cluster profiles. Closely related patterns were assigned an additional capital letter.

PFGE was performed according to the PulseNet protocol (CDC/PulseNet with modifications using the ApaI and SmaI restriction enzymes (GRAVES \& SWAMINATHAN, 2001). Bacterial cells embedded in agarose (plugs) with lisozyme $\left(10 \mathrm{mg} \mathrm{mL}^{-1}\right)$ were lysed in lysis buffer $[50 \mathrm{mM}$ Tris $\mathrm{pH}$ 8.0, 50mM EDTA pH 8.0, 1.0\% sarcosil, 0.15mg $\mathrm{mL}^{-1}$ proteinase $\mathrm{K}$ ] for two hours at $54^{\circ} \mathrm{C}$ in a water bath with agitation. After that, the plugs were washed twice in type I water and four times in TE buffer (10mM Tris, $1 \mathrm{mM}$ EDTA pH 8.0).

The digestion of each DNA sample in the plugs was carried out by using two restriction enzymes, ApaI (40U, $30^{\circ} \mathrm{C}$, overnight) and SmaI $\left(20 \mathrm{U}, 25^{\circ} \mathrm{C}\right.$ overnight). The pulsed field gel electrophoresis was performed in $1 \%$ agarose gel (agarose running gel, Sigma, USA) in Tris-boric acid-EDTA 0.5X [90mM Tris, 90mM boric acid $\mathrm{pH} 8.0$ and 2mM EDTA] in the CHEF DRII system (Bio-Rad Laboratories) at 6V $\mathrm{cm}^{-1}, 14^{\circ} \mathrm{C}$ for $19 \mathrm{~h}$ with switch times of $4 \mathrm{~s}$ to $40 \mathrm{~s}$. The molecular weight lambda DNA PFGE ladder (New England Biolabs, Ipswich, MA) was positioned at the ends of each gel. To confirm the genetic profile of strains, the technique was performed in triplicate. 
Images were obtained with a Bio-Rad Gel Doc XR system, using the software Quantity One 4.4.1 (Bio-Rad Laboratories), after staining with GelRed for 15 minutes. Comparison of the PFGE patterns was made using the BioNumerics software package (version 4.5; Applied Maths, Belgium). The similarity between the strains was determined by the Dice coefficient and dendrograms were created by using the unweighted pair group method with arithmetic averages - UPGMA. A cutoff value of $80 \%$ was set to determine the clusters similarity as performed by FRANCIOSA et al. (2005) and identified with Arabic numbers. The pulsotypes (PT) were used to identify strains with unique electrophoretic profiles, and subtypes (ST) with profiles up to three bands of difference were indicated by using capital letters and numbers, respectively.

\section{RESULTS AND DISCUSSION}

From the 30 samples of raw ground beef, five $(16.7 \%)$ tested positive for Listeria monocytogenes, three of them belonging to serotype $1 / 2 \mathrm{~b}$ and two of them belonging to serotype $4 \mathrm{~b}$. From the 30 samples of fresh mixed sausage evaluated, two strains $(6.7 \%)$ of $L$. monocytogenes were isolated, one belonging to serotype $1 / 2 \mathrm{a}$ and the other to serotype $1 / 2$ b. According to KATHARIOU (2002), $1 / 2 \mathrm{a}, 1 / 2 \mathrm{~b}$ and $4 \mathrm{~b}$ are the serotypes most frequently involved in human listeriosis.

The profile analysis by PFGE macrorestriction and the results obtained with the restriction enzyme ApaI (Figure 1) allowed the distribution of the seven strains in one cluster $(>80 \%$ similarity), two pulsotypes (A and B) and two subtypes (A1 and B1). The pulsotypes B comprised four samples, two from ground beef and two from frescal sausage. Three of these samples were classified as serotype $1 / 2 \mathrm{~b}$ and one as serotype $1 / 2 \mathrm{a}$ showing the genetic similarity between these strains.

The profile generated with the restriction enzyme SmaI was similar to the results obtained when using ApaI enzyme, except for clustering. After SmaI enzyme digestion the strains were grouped into two clusters ( 1 and 2, >80\% similarity) (Figure 2). According to figures 1 and 2, the SmaI enzyme digestion gave a more discriminating result than the ApaI enzyme digestion.

Even though listeriosis can be caused by any of the 13 L. monocytogens serotypes (LEMESMARQUES et al., 2007), it is known that $1 / 2 \mathrm{a}, 1 / 2 \mathrm{~b}$ and $4 \mathrm{~b}$ serotypes are responsible for almost $90 \%$ of outbreaks and sporadic cases worldwide (LÓPEZ et al., 2006). In this study, it was found that the isolates of L. monocytogenes serotypes $4 \mathrm{~b}, 1 / 2 \mathrm{a}$ and $1 / 2 \mathrm{~b}$ were strongly correlated within the same serotypes and, in some cases, between the different serotypes, indicating a common origin. The same results were observed by other authors (PARIHAR, et al., 2008).

The discrimination of results obtained by using different enzymes can vary even in isolates of the same origin, as happened in this study between the enzymes ApaI and SmaI. Likewise, YDE \& GENICOT (2004) explained that the discrimination of three strains sent to the Belgian Reference Center varied depending on which enzyme they were digested with: two of them showed an identical profile when digested with AscI enzyme, but were different with ApaI enzyme. Furthermore, SHEN et al. (2006) also found differences in the discrimination of bands between the enzymes AscI and ApaI.

There is a discussion about the relationship of the origin of two lineages found in $\boldsymbol{L}$. monocytogenes, the lineage I represented by serovars $1 / 2 \mathrm{~b}$ and $4 \mathrm{~b}$, and the lineage II represented by serovars 1/2a and 1/2c (PARIHAR et al., 2008). According to

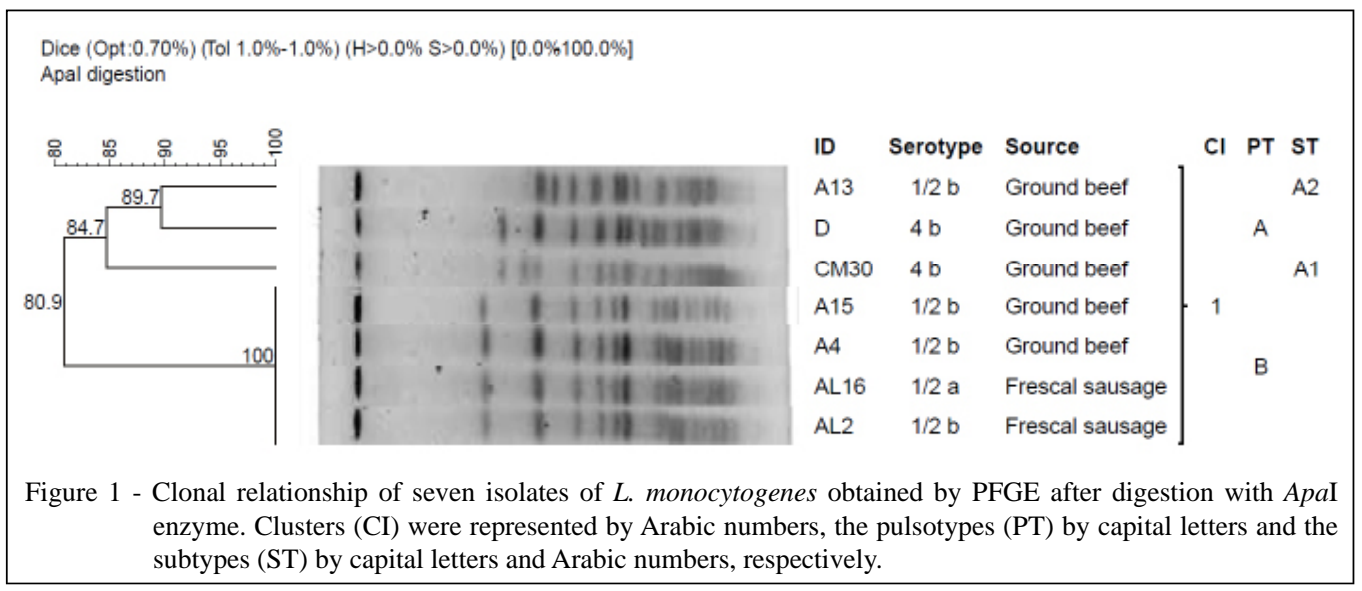

Ciência Rural, v.43, n.8, ago 2013. 


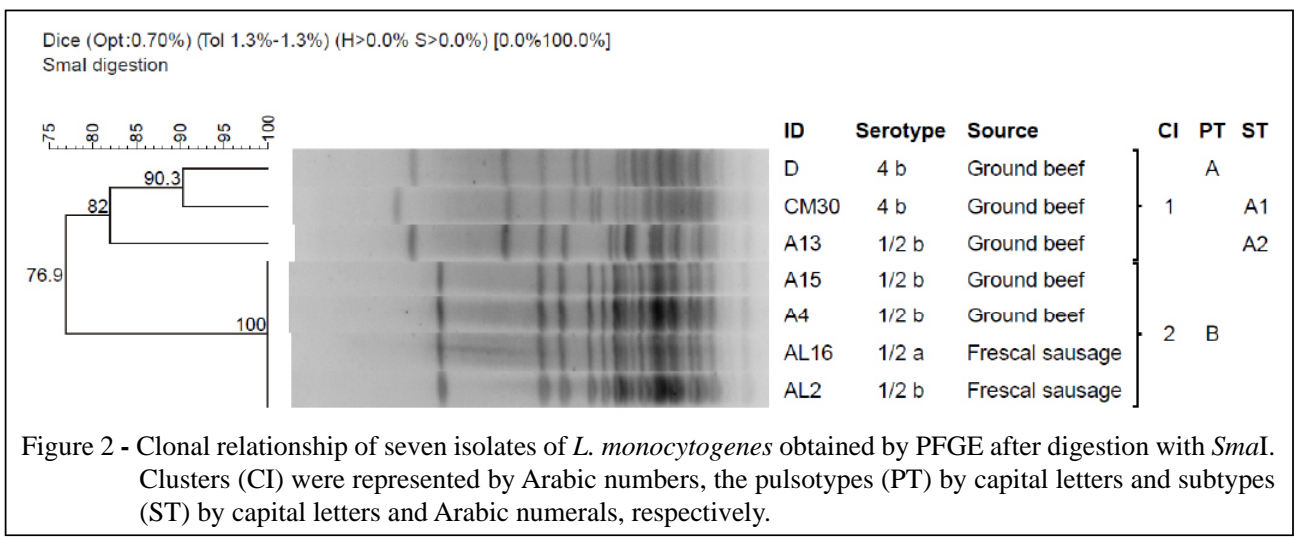

NIGHTINGALE et al. (2005), lineage I comprises the strains which have adapted to the human host, while lineage II comprises the strains which have been environmentally adapted.

In this sense, it is necessary to identify $\boldsymbol{L}$. monocytogenes in different environments in order to associate them with the different pulsotypes described for human listeriosis. However in Brazil, data from both human and environment samples isolation has been scarce, especially in the second case. Therefore, in our country, a map of the geographical and temporal distribution of the occurrence of $\boldsymbol{L}$. monocytogenes (and much less of their pulsotypes) does not yet exist (LEMES-MARQUES et al., 2007).

Considering the handmade preparation of frescal sausage, mostly from unknown origin, it was not possible to establish the persistence of $\boldsymbol{L}$. monocytogenes, as suggested by LONCAREVIC et al. (1996) who reported the persistence of this Listeria in processing plants where the products may have been continuously contaminated. This was confirmed by VON LAER et al. (2009) who analyzed samples of frescal sausage from a processing line in Pelotas, Brazil. These authors observed no contamination by $\boldsymbol{L}$. monocytogenes in the raw material, but the pathogen was detected in all the final product samples.

Sometimes the $L$. monocytogenes that persists in a production line for a long period of time may be regarded as a dominant strain (RORVIK et al., 2003). This fact emphasizes the importance of the environment as a source of food products contamination.

Thus, it is important to emphasize the disagreement related to the determination of the main sources of $\boldsymbol{L}$. monocytogenes contamination. While some authors consider the importance of the equipment and the environment, others believe that the raw material would be the most common source of contamination.

\section{CONCLUSION}

The molecular analysis showed that the L. monocytogenes strains were identical or closely related even though they were obtained from products sold in different places and collected at different times. This would suggest the environment as a common source of the food products contamination.

In order to prevent outbreaks of human and animal listeriosis, molecular techniques such as PFGE are important tools that allow prevalence studies to identify and recall contaminated products. It is recommended a surveillance program in this matter from public health authorities once highly virulent listeriosis serotypes were detected in samples coming from Araguaina, northern Brazil.

\section{ACKNOWLEDGMENTS}

The authors would like to thank the Centre for Food Research in the Veterinary School, the Postgraduate Coordination in Animal Sciences and the Institute of Tropical Pathology and Public Health from the Federal University of Goias, Brazil. The authors would also like to thank Dr. Ernesto Hofer from the Bacterial Zoonoses Laboratory (FIOCRUZ, RJ) for serotyping $\boldsymbol{L}$. monocytogenes.

\section{REFERENCES}

BASIM, E.; BASIM, H. Pulsed-field gel electrophoresis (PFGE) technique and its use in Molecular Biology. Turkish Journal of Biology, v.25, n.4, p.405-418, 2001. Available from: <http:// journals.tubitak.gov.tr/biology/issues/biy-01-25-4/biy-25-4-60006-5.pdf>. Accessed: Oct. 15, 2012.

BRASIL. Ministério de Agricultura do Abastecimento e da Reforma Agrária. Secretaria de Defesa Agropecuária. Métodos analíticos oficiais para análises microbiológicas para controle de produtos de origem animal e água. Instrução Normativa n.62, de 26 de agosto de 2003. Available from: <http://www.hidrolabor. com.br/IN62.pdf>. Accessed: Oct. 15, 2012.

FILIOUSIS, G. et al. Prevalence, genetic diversity and antimicrobial susceptibility of Listeria monocytogenes isolated 
from open-air food markets in Greece. Short Communication. Food Control, v.20, n.3, p.314-317, 2009. Available from: <http:// dx.doi.org/10.1016/j.foodcont.2008.05.018>. Accessed: Oct. 15, 2012. doi: 10.1016/j.foodcont.2008.05.018.

FRANCIOSA, G. et al. Molecular and experimental virulence of Listeria monocytogenes strains isolated from cases with invasive listeriosis and febrile gastroenteritis. FEMS Immunology and Medical Microbiology, v.43, n.3 p.431-439, 2005 Available from: <http://onlinelibrary.wiley.com/doi/10.1016/j. femsim.2004.11.005/pdf>. Accessed: Oct. 15, 2012. doi: 10.1016/j. femsim.2004.11.005.

FUGETT, E.B. et al. Pulsed-field gel electrophoresis (PFGE) analysis of temporally matched Listeria monocytogenes isolates from human clinical cases, foods, ruminant farms, and urban and natural environments reveals source-associated as well as widely distributed PFGE types. Journal of Clinical Microbiology, v.45, n.3, p.865-873, 2007. Available from: <http://jcm.asm. org/content/45/3/865>. Accessed: Oct. 15, 2012. doi: 10.1128/ JCM.01285-06.

GRAVES, L.M. et al. Subtyping Listeria monocytogenes. In: BROCK TH.D.; MADIGAN, M.T. Listeria, Listeriosis, and food safety. New Jersey: Prentice-Hall, 1999. Chap.9, p.279-297.

GRAVES, L.M. et al. Microbiological aspects of the investigation that traced the 1998 outbreak of listeriosis in the United States to contaminated hot dogs and establishment of molecular subtyping-based surveillance for Listeria monocytogenes in the PulseNet Network. Journal of Clinical Microbiology, v.43, n.5, p.2350-2355, 2005. Available from: <http://dx.doi.org/10.1128/ JCM.43.5.2350-2355.2005>. Accessed: Jun. 24, 2011. doi: 10.1128/JCM.43.5.2350-2355.2005.

GRAVES, L.M.; SWAMINATHAN, B. PulseNet standardized protocol for subtyping Listeria monocytogenes by macrorestriction and pulsed-field gel electrophoresis. International Journal of Food Microbiology, v.65, p.55-62, 2001. Available from: <http:// dx.doi.org/10.1016/S0168-1605(00)00501-8>. Accessed: Oct. 15, 2012. doi: 10.1016/S0168-1605(00)00501-8.

GRAY, M.J. et al. Listeria monocytogenes isolates from foods and humans form distinct but overlapping populations. Applied and Environmental Microbiology, v.70, n.10. p.5833-5841, 2004. Available from: <http://aem.asm.org/content/70/10/5833. short>. Accessed: Oct. 15, 2012. doi: 10.1128/AEM.70.10.58335841.2004

JACQUET, C. et al. Expression of ActA, Ami, InlB, and Listeriolysin o in Listeria monocytogenes of human and food origin. Applied and Environmental Microbiology, v.68, n.2, p.616-622 2002. Available from: <http://aem.asm.org/content/68/2/616>. Accessed: Oct. 15, 2012. doi: 10.1128/AEM.68.2.616-622.2002.

KATHARIOU, S. Listeria monocytogenes virulence and pathogenicity, a food safety perspective. Journal of Food Protection, v.65, n. 11, p.1811-1829, 2002. Available from: <http://www.ncbi.nlm.nih.gov/pubmed/12430709>. Accessed: Jun. 24, 2011.

LEMES-MARQUES, E.G. et al. Pheno- and genotypic characterization of Listeria monocytogenes clinical isolates from southwestern region of the State of São Paulo, Brazil. Brazilian Journal of Microbiology, v.38, n.2. p.287-292, 2007. Available from: <http://dx.doi.org/10.1590/S1517-83822007000200019> Accessed: Jun. 24, 2011. doi: 10.1590/S1517-83822007000200019.
LONCAREVIC, S. et al. The clones of Listeria monocytogenes detected in food depend on the method used. Letters in Applied Microbiology, v.22, n.5, p.381-384, 1996. Available from: <http:// dx.doi.org/10.1111/j.1472-765X.1996.tb01184.x>. Accessed: Jun. 24, 2011. doi: 10.1111/j.1472-765X.1996.tb01184.x.

LÓPEZ, V. et al. Listeria monocytogenes en alimentos: son todos los aislamientos igual de virulentos? Revista Argentina de Microbiología, v.38, n.4, p.224-234, 2006. Available from: <http:// www.scielo.org.ar/pdf/ram/v38n4/v38n4a11.pdf >. Accessed: Oct. 15,2012 .

MELLO, J.F. et al. Molecular analysis of the LAP gene of Listeria monocytogenes isolated from cheeses in Rio Grande do Sul, Brazil. Brazilian Journal of Microbiology, v.39, n.1, p.169172, 2008. Available from: <http://dx.doi.org/10.1590/S151783822008000100033>. Accessed: Jun. 24, 2011. doi: 10.1590/ S1517-83822008000100033.

MORETRO, T.; LANGSRUD, S. Listeria monocytogenes: Biofilm formation and persistence in food-processing environments. Biofilms, v.1, n.2, p.107-121, 2004. Available from: <http://dx.doi. org/10.1017/S1479050504001322>. Accessed: Jun. 24, 2011. doi: $10.1017 / \mathrm{S} 1479050504001322$.

NIGHTINGALE, K.K. et al. Evolution and molecular phylogeny of Listeria monocytogenes isolated from human and animal listeriosis cases and foods. Journal of Bacteriology, v.187, n.16, p.5537-5551, 2005. Available from: <http://www.ncbi.nlm.nih. gov/pmc/articles/PMC1196091/>. Accessed: Oct. 14, 2012. doi: 10.1128/JB.187.16.5537-5551.2005.

PARIHAR, V.S. et al. Characterization of human invasive isolates of Listeria monocytogenes in Sweden 1986-2007. Foodborne Pathogens and Disease, v.5, n.6, p.755-761, 2008. Available from: <http://dx.doi.org/10.1089/fpd.2008.0123>. Accessed: Oct. 15, 2012. doi: 10.1089/fpd.2008.0123.

ROCOURT, J. The genus Listeria and Listeria monocytogenes: Phylogenetic position, taxonomy, and identification. In: BROCK TH.D.; MADIGAN, M.T. Listeria, Listeriosis, and food safety. New Jersey: Prentice-Hall, 1999. Chap.1, p.1-20.

RORVIK, L.M. et al. Molecular epidemiological survey of Listeria monocytogenes in broilers and poultry products. Journal of Applied Microbiology. v.94, n.4, p.633-640, 2003. Available from: <http://dx.doi.org/10.1046/j.1365-2672.2003.01895.x>. Accessed: Jun. 24, 2011. doi: 10.1046/j.1365-2672.2003.01895.x.

SENCZEK, D. et al. Pulsed-field gel electrophoresis (PFGE) typing of Listeria strains isolated from a meat processing plant over a 2-year period. International Journal of Food Microbiology, v.62, n.1-2, p.155-159, 2000. Available from: <http://dx.doi. org/10.1016/S0168-1605(00)00395-0>. Accessed: Jun. 24, 2011. doi: 10.1016/S0168-1605(00)00395-0.

SHEN, Y. et al. Isolation and characterization of Listeria monocytogenes isolates from ready-to-eat foods in Florida. Applied and Environmental Microbiology, v.72, n.7, p.5073-5076, 2006. Available from: <http://dx.doi.org/10.1128/AEM.00435-06>. Accessed: Jun. 24, 2011. doi: 10.1128/AEM.00435-06.

TENOVER, F.C. et al. Interpreting chromosomal DNA restriction patterns produced by Pulsed-Field Gel Electrophoresis: criteria for bacterial strain typing. Journal of Clinical Microbiology, v.33, n.9, p.2233-2239, 1995. Available from: <http://www.ncbi.nlm. 
nih.gov/pmc/articles/PMC228385/pdf/332233.pdf>. Accessed: Oct. 15, 2012.

TENOVER, F.C. et al. How to select and interpret molecular strain typing methods for epidemiological studies of bacterial infections: a review for healthcare epidemiologists. Infection Control and Hospital Epidemiology, v.18, n.6, p.61-74, 1997. Available from: 〈http://biomedica.eng.uminho.pt/rrb/pdfs/molecularepi97.pdf > Accessed: Jun. 24, 2011.

VON LAER, A.E. et al. Characterization of Listeria monocytogenes isolated from a fresh mixed sausage processing line in Pelotas-RS by PFGE. Brazilian Journal of Microbiology, v.40, n.3, p.574582, 2009. Available from: <http://dx.doi.org/10.1590/S151783822009000300021>. Accessed: Jun. 24, 2011. doi: 10.1590/ S1517-83822009000300021.

YDE, M.; GENICOT, A. Use of PFGE to characterize clonal relationships among Belgian clinical isolates of Listeria monocytogenes. Journal of Medical Microbiology, v.53, n.5, p.399-402, 2004. Available from: <http://dx.doi.org/10.1099/ jmm.0.05356-0>. Accessed: Jun. 24, 2011. doi: 10.1099/ jmm.0.05356-0. 